\title{
KEBIJAKAN PUBLIK DALAM KONSTELASI PARADIGMA PEMBANGUNAN KESEJAHTERAAN SOSIAL
}

\author{
Ronawaty Anasiru \\ Fakultas Ilmu Sosial dan Ilmu Politik Universitas Indonesia Timur Makassar \\ Jl. Rappocini Raya No.171-173 Makassar \\ Telp.(0411) 421974, Fax (0411) 852111
}

\section{ABSTRAK}

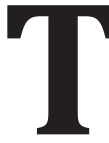

lulisan ini akan menyampaikan beberapa gagasan mengenai peran Negara dalam kebijakan publik dan pembangunan sosial, khususnya yang menyangkut pembangunan kesejahteraan sosial di Indonesia. Tulisan ini dilandasi argumen bahwa menguatnya arus globalisasi dan liberalism ekonomi melahirkan kesempatankesempatan dan pilihan-pilihan baru dalam berbagai bidang pembangunan. Namun demikian, kapitalisme sebagai anak kandung globalisasi dan sekaligus poros dari liberalisme ekonomi juga menciptakan tantangan-tantangan baru bagi pembangunan Indonesia. Kebijakan publik yang pro pembangunan sosial diperlukan guna merebounding dominasi globalisasi dan kapitalisme sehingga tidak menabrak keadilan dan kesejahteraan sosial.

Kata Kunci: Kebijakan publik, pembangunan, kesejahteraan sosial

\section{A. PENDAHULUAN}

Menurut Undang-Undang No.11 tahun 2009 tentang kesejahteraan sosial. Kesejahteraan sosial adalah kondisi terpenuhinya kebutuhan spiritual, material dan sosial warga Negara agar dapat hidup layak dan mampu mengembangkan diri, sehingga dapat melaksanakan fungsi sosialnya

Kesejahteraan sosial adalah bagian tak terpi-sahkan dari cita-cita kemerdekaan dan muara dari agenda pembangunan ekonomi. Pasal 33 UUD 1945 yang merupakan pasal mengenai ekonomi berada pada bab.XIV UUD 45 yang berjudul "kesejahteraan sosial".
Menurut Sri Edi Swasono (2001), dengan menempatkan pasal 331945 dibawah judul bab "kesejahteraan sosial" itu berarti pembangunan ekonomi nasional haruslah bermuara pada peningkatan kesejahteraan sosial. Dengan demikian, dilihat dari perspektif pembangunan sosial, Indonesia menganut Negara kesejahteraan, Indonesia menganut prinsip keadilan sosial (sila kelima Pancasila) dan secara eksplisit konstitusinya (pasal 27 dan 34 UUD 1945) mengamanatkan tanggungjawab pemerintah dalam pembangunan sosial. 
Namum demikian, baik pada masa Orde Baru maupun era reformasi saat ini, pembangunan sosial baru sebatas jargon dan belum terintegrasi dengan strategi pembangunan ekonomi. Penanganan masalah sosial masih belum menyentuh persoalan mendasar. Program-program jaminan sosial masih bersifat parsial dan karitatif serta belum didukung oleh kebijakan publik yang memadai. Orang miskin masih dipandang sebagai sampah pembangunan yang harus dibersihkan. Kalaupun dibantu, baru sebatas bantuan uang, barang, pakaian atau mie instan berdasarkan prinsip belas kasihan (harity) tanpa konsep dan visi yang jelas.

Bahkan kini terdapat kecenderungan pemerintah enggan terlibat mengurusi permasalahan sosial. Dengan menguatnya liberalisme dan kapitalisme, pemerintah lebih tertarik pada bagaimana memacu pertumbuhan ekonomi setinggi-tingginya termasuk menarik pajak dari rakyat sebesar-besarnya. Sedangkan tanggungjawab menangani masalah sosial dan memberikan jaminan sosial diserahkan sepenuhnya kepada masyarakat.

Bergulirnya otonomi daerah juga bukan semakin memperkuat komitmen pemerintah daerah untuk lebih memperhatikan masyarakat kelas bawah. Pemberian wewenang yang lebih besar kepada pemerintah daerah dalam mengelola pembangunan daerah belum diikuti dengan penguatan piranti kebijakan dan strategi pembangunan sosial. Bahkan terdapat ironi di beberapa daerah institusi-institusi kesejahteraan sosial yang sudah mapan, alihalih dibina kembangkan malahan dibumi hanguskan begitu saja.

Terkesan kuat, pengalihan pembangunan sosial hanya dianggap sebagai beban tambahan bagi anggaran pemerintah daerah. Tidak sedikit pemerintah daerah yang hanya mau menerima penguatan dan peralihan wewenang dalam pengelolaan dan peningkatan sumber-sumber "Pendapatan Asli Daerah (PAD)" sedangkan peralihan tugas dan peran menangani "Permasalahan Sosial Asli Daerah (PSAD) inginnya diserahkan kepada masyarakat, lembaga-lembaga sosial dan keagamaan.

Indonesia bisa menimba pengalaman dari Negara-negara maju ketika mereka memanusiawikan kapitalisme. Kemiskinan dan kesenjangan sosial ditanggulangi oleh kebijakan publik, seperti berbagai skim jaminan sosial yang benar-benar dapat dirasakan manfaatnya secara nyata terutama oleh masyarakat kelas bawah.

\section{B. KEBIJAKAN PUBLIK}

Istilah kebijakan adalah suatu kemampuan atau kemahiran, sedangkan kebijakan publik adalah suatu pernyataan atau kehendak dari pemerintah mengenai suatu kegiatan yang dilakukannya dalam suatu bidang tertentu untuk peningkatan kesejahteraan masyarakat. Literatur mengenai kebijakan publik telah banyak menyajikan berbagai definisi kebijakan publik, baik dalam arti luas maupun sempit. Dye yang dikutip Young dan Quinn (2005:2), memberikan definisi kebijakan publik secara luas, yakni sebagai "whatever governments choose to do or not to do". Untuk memahami berbagai definisi kebijakan publik ada baiknya jika kita membahas beberapa konsep kunci yang termuat dalam kebijakan publik.

a. Kebijakan publik adalah Tindakan pemerintah yang berwewenang. Kebijakan publik adalah tindakan yang dibuat dan diimplementasikan oleh badan pemerintah yang memiliki kewenangan hukum, politis dan finansial untuk melakukannya.

b. Kebijakan publik adalah sebuah reaksi terhadap kebutuhan dan masalah dunia nyata. Kebijakan publik berupaya merespon masalah atau kebutuhan kongkrit yang berkembang di masyarakat.

c. Kebijakan publik adalah seperangkat tindakan yang berorientasi pada tujuan. Kebijakan publik biasanya bukanlah sebuah keputusan tunggal melainkan terdiri dari beberapa pilihan tindakan atau strategi yang dibuat untuk mencapai tujuan tertentu demi kepentingan orang banyak.

d. Kebijakan publik adalah sebuah keputusan untuk melakukan atau tidak melakukan sesuatu. Kebijakan publik pada umumnya merupakan tindakan kolektif untuk memecahkan masalah sosial. Namun, kebijakan publik bisa juga dirumuskan 
berdasarkan keyakinan bahwa masa-lah sosial akan dapat dipecahkan oleh kerangka kebijakan yang sudah ada dan karenannya tindakan memerlukan tindakan tertentu.

\section{PARADIGMA PEMBANGUNAN KESEJAHTERAAN SOSIAL}

Saat ini terjadi pergeseran paradigma dalam ketatanegaraan dan kebijakan publik dari goverment (pemerintahan) ke governance (tata kelola), kebijakan publik dipandang bukan lagi sebagai dominasi pemerintah. Makna publik juga bergeser dari "penguasa orang banyak" yang diindentik dengan pemerintah ke "bagi kepentingan orang banyak dengan istilah stakeholder atau pemangku kepentingan. Para analis kebijakan dan kelompok pemikir yang independen kemudian muncul sebagai profesi baru yang banyak berperan mengkritisi beroperasinya kebijakan sosial dan kemudian mengajukan saran-saran perbaikannya demi terwujudnya good governance sejalan dengan menguatnya semangat demokratisasi, civil society dan transparansi.

Secara konseptual, pembangunan kesejahteraan sosial merupakan bagian integral dari pembangunan sosial. Dalam Pembangunan Nasional kesejahteraan sosial merupakan bagian integral dari pembangunan bidang kesejahteraan rakyat, pendidikan dan kebudayaan. Oleh karena itu, di Indonesia kesejahteraan sosial secara luas merujuk pada pembangunan sosial, sedangkan secara sempit mengacu pada pembangunan kesejahteraan sosial.

Edi Soeharto dalam bukunya Analisis kebijakan publik menyatakan bahwa "Pembangunan kesejahteraan sosial adalah usaha yang terencana dan terarah yang meliputi berbagai bentuk intervensi sosial dan pelayanan sosial untuk memenuhi kebutuhan manusia, mencegah dan mengatasi masalah sosial, serta memperkuat institusi-institusi sosial. Ciri iutama pembangunan kesejahteraan sosial adalah holistik-komprehensif dalam arti setiap pelayanan sosial yang diberikan senantiasa menempatkan penerima pelayanan (beneficiaries) sebagai manusia, baik dalam arti individu maupun kolektifitas, yang tidak terlepas dari sistem lingkungan sosiokulturalnya.

Perkembangan globalisasi dan menguatnya interaksi antar peradaban dunia telah memperkuat masuknya paham ekonomi kapitalisme dalam berbagai pendekatan pembangunan. Secara makro, masuknya faham ekonomi kapitalisme ini telah mdelahirkan kritikan tajam terhadap faham welfare state (Negara kesejahteraan). Sehingga berkembang anggapan bahwa negara kesejahteraan merupakan sistem yang boros, tidak mampu memberdayakan masyarakat, menimbulkan stigmatisasi dan bahkan jebakan kemiskinan (poverty trap) terhadap populasi sasarannya.

Meskipun kritik tersebut tidak sepenuhnya akurat anggapan ini telah menyebabkan menurunnya anggaran pembangunan yang dialokasikan untuk usaha kesejahteraan sosial. Usaha ini dipandang sebagai kegiatan yang tidak memiliki indikator keberhasilan yang terukur secara ekonomis. Menghadapai tantangan ini pembangunan kesejahteraan sosial mengalami pergeseran paradigma (paradigm shift) yakni :

\section{Dari masalah ke kebutuhan}

Selama ini pembangunan kesejahteraan sosial lebih berorientasi pada penanganan masalah, khususnya masalah kesejahteraan soaial. Meskipun bukan kekeliruan, pendekatan semacam ini seringkali menggiring pada pembuat keputusan dan pelaku pembangunan kesejahteraan sosial kepada pendekatan bersifat reaktif. Program pembangunan kesejahteraan sosial dirancang hanya untuk mengatasi masalah yang sudah ada diwilayah hilir. Hal ini sejalan dengan teori "gunung es" atau "Iceberg theory" dari Anderson dimana melihat suatu permasalahan hanya dari permukaan saja yang bersifat reaktif, tidak melihat masalah yang mendasar yang ada dibawah gunung es tersebut. Sebagaimana dicontohkan para pekerja sosial berperilaku seperti "tukang sampah" yang setiap hari membersihkan sampah tanpa pernah merespon sumber penghasil sampah.

Disadari bahwa kesejahteraan sosial bersifat multidimensional, penanganannya 
membutuhkan pendekatan terpadu yang tidak hanya difokuskan pada gejala masalah, melainkan pada berbagai determinan yang mempengaruhinya. Perspektif penanganan masalah sosial yang berorientasi pada kebutuhan dapat dilihat dari programprogram kesejahteraan sosial yang bersifat pencegahan dan pengembangan yang kini banyak dikembangkan di negara maju dan berkembang.

\section{Dari stigmatisasi ke hak azasi manusia}

Pada masyarakat barat, sejarah perkembangan usaha kesejahteraan sosial tidak dapat dilepaskan dari kegiatan-kegiatan karitatif untuk menolong keluarga miskin. Para penerima pelayanan diberi bantuan uang, barang atau pelayanan sosial untuk menunjang hidupnya, karena prasyarat menerima bantuan adalah memenuhi kriteria "miskin" dan "tidak mampu, para penerima pelayanan ini dengan sendirinya termasuk ke dalam kelompopk khusus. Mereka mengalami stigmatisasi sebagai warga kelas dua pada struktur sosial masyarakat. Konsep kesejahteraan kemudian sangat identik dengan pemberian tunjangan pendapatan (doll) atau tunjangan pengangguran (unemployment benefits) bagi golongan masyarakat yang papa, cacat atau menganggur.

Dewasa ini dengan diratifikasinya berbagai konvensi hak azasi mananusia, bantuan terhadap kaum papa sekalipun tidak lagi dilihat sebagai usaha belas kasihan (charity). Melainkan sebagai hak mereka sebagai warga negara untuk menerima pelayanan sosial dasar dari Negara sebagai representasi masyarakat. Beberapa istilah yang telah bertahun-tahun digunakan dalam arena kesejahteraan sosial mengalami berbagai penyelarasan. Misalnya orang miskin (the poor) menjadi "pemerlu" (the needy), orang cacat (handicapped disabled people) menjadi "orang dengan kecacatan" (people withdisabilities) atau "orang dengan kemampuan khusus (people with specific capacities). Kelompok sasaran ini yang tadinya hanya dipandang sebagai "penerima pelayanan" (beneficiares) atau "klien"(client), kemudian ada yang sering dinamakan "pengguna" (user). Istilah pengguna dimasukkan sebagai salah satu populasi dan "kelompok yang berkepentingan" (stakeholders) dan dipandang sebagai kelompok penentu proses keberhasilan pertolongan.

\section{Dari penerima positif ke pelaku aktif}

Salah satu kritik yang sering dilontarkan kepada sistem welfare state adalah terlau dominannya peran Negara dalam merancang dan sekaligus melakukan intervensi terhadap populasi yang mengalami masalah. Selain meninmbulkan beban pada anggaran negara, pendekatan ini sering menimbulkan ketergantungan pada penerima pelayanan sosial. Dalam praktek pekerjaan sosial, pekerja sosial dipandang sebagai penolong yang serba bisa. Sementara klien dilihat sebagai penerima bantuan yang seakan-akan tidak memiliki kemampuan untuk menolong dirinya.

Pandangan diatas kini telah banyak bergeser. Negara kini banyak menyerahkan sebagian peran sosialnya kepada Lembaga Swadaya Masyarakat (LSM) sebagai mitra kerjasama pembangunan kesejahteraan sosial. Klien kini dipandang sebagai aktor yang juga memiliki potensi yang dapat dikembangkan untuk menghadapi masalahnya sendiri. Konsep pemberdayaan menyeruk sebagai strategi pembangunan kesejahteraan sosial yang menempatkan penerima pelayanan bukan semata-mata "klien" melainkan "partisipan" dan "pelaku aktif" pemenuhan kebutuhan mereka sendiri.

\section{Dari bantuan sosial ke pemberdayaan.}

Dengan menguatnya embusan demokrasi dan semangat civil society, konsep mengenai pemberdayaan masyarakat (community empowerment) semakin mendapat tempat dalam relung kesadaran publik. Pembangunan kesejahteraan sosial yang semula didominasi negara, kini dilakukan dengan melibatkan masyarakat dan organisasi-organisasi sosial. Karena belanja negara untuk program kesejahteraan sosial mengalami kontraksi, program-program jaminan sosial dan pelayanan sosial yang semula bersifat universal, kini semakin bergeser menjadi selektif berdasarkan pendekatan means-test. Isu-isu mengenai stigma, kergantungan dan 
"jebakan kemiskinan" (poverty trap) yang sering dianggap melekat pada pelayanan dan bantuan sosial, telah menjadi justifikasi logis bagi masuknya nuansa pemberdayaan pada mainstream pembangunan kesejahteraan sosial

\section{KONSTELASI PARADIGMA PEMBANGUNAN KESEJAHTERAAN SOSIAL}

Pandangan di atas mencerminkan bahwa pembangunan kesejahteraan sosial berorientasi dan berwawasan ke depan searah dengan perubahan dan perkembangan masyarakat. Pembangunan kesejahteraan sosial bukan hanya bersifat residual, reaktif dan karitatif dalam arti hadir hanya sebagai pelipur lara terhadap para penyandang masalah sosial dan memainkan peran hanya sebagai "penyapu sampah-sampah pembangunan". Pendekatan pembangunan kesejahteraan sosial bersifat universal. Institusional dan proaktif terhadap kondisi kehidupan masyarakat dan masalah sosial. Sasaran pembangunan kesejahteraan sosial adalah seluruh masyarakat dari berbagai latar dan golongan dengan prioritas utama para penyandanga masalah sosial Pemerlu Pelayanan Kesejahteraan Sosial (PPKS). Pembangunan kesejahteraan sosial dilaksanakan secara bertahap, terarah, terpadu, berkelanjutan, berencana, terorganisasi dan melembaga.

Pembangunan kesejahteraan sosial menekankan pada keberfungsian sosial (social functioning) manusia dalam kehidupan sosial masyarakat. Tujuan pembangunan kesejahteraan sosial adalah tercapainya kondisi kesejahteraan sosial yang adil dan merata serta berjalannya suatu sistem kesejahteraan sosial yang mapan dan melembaga sebagai salah satu piranti kehidupan masyarakat Indonesia dalam upaya menjadi bangsa yang maju, mandiri dan mampu memenuhi kebutuhan hidupnya sesuai dengan standard kemanusiaan.

Pembangunan akan memberikan hasil yang optimal apabila memperhatikan berbagai dimensi secara seimbang dan proporsional. Untuk memacu dan mempertahankan pertumbuhan ekonomi serta mewujudkan kesejahteraan sosial yang adil, pendekatan pembangunan harus mempertimbangkan aspek-aspek sosial. Pendekatan sosial perlu diterapkan bersamaan dengan pendekatan ekonomi dalam strategi pembangunan. Keduanya harus dirancang dan dilaksanakan secara seimbang, saling mengisi, saling melengkapi, dan saling memperkuat satu sama lain. Pembangunan sosial dan kebijakan sosial kemudian muncul sebagai konsep baru yang mewarnai konstelasi paradigma pembangunan sebelumnya yang terlalu didominasi oleh pembangunan ekonomi dan tentunya oleh kebijakan ekonomi.

\section{F. PENUTUP.}

Demikianlah ulasan tentang Kebijakan publik dalam konstelasi pareadigma pembangunan kesejahteraan sosial. Terlepas dari kelemahan dan kelebihannya memberi pesan betapa sebuah naskah kebijakan adalah produk akademis yang tidak kaku. Bila isi dan tampilannya menarik, ia dapat mengundang perhatian publik dan berpengaruh pada perubahan masyarakat, for better or worst. Karenanya, naskah kebijakan adalah piranti pembangunan sosial yang sangat penting menjadi bagian strategi pembangunan nasional.

\section{DAFTAR PUSTAKA}

Anderson. E. James (1984) Public Police Making, Holt, Rinehart and Winston, CBS College Publishing, New York.

Suharto, Edi. (2005) Analisis Kebijakan Publik (Panduan Praktis Mengkaji Masalah dan Kebijakan Sosial) Bandung: Alfabeta. 